\title{
Prognostic role of vitamin D receptor in breast cancer: a systematic review and meta-analysis
}

Haiyan $\mathrm{Xu}^{1 \dagger}$, Zhenhua Liu ${ }^{2 \dagger}$, Hongtai Shi ${ }^{3^{*}}$ (D) and Chunbin Wang ${ }^{4^{*}}$

\begin{abstract}
Background: A higher vitamin D intake improves the prognosis of early stage breast cancer (BC) patients. We hypothesized that vitamin D intake should refer to vitamin D receptor (VDR) expression. In order to prove this hypothesis, we first intend to evaluate the correlation between VDR expression and prognosis of BC patients using meta-analysis.
\end{abstract}

Methods: Literatures from PubMed, Embase, and the Cochrane Library (last update by May 20, 2020) were retrieved to find studies assessing the prognostic role of VDR in BC. The hazard ratios (HRs) for patients' survival were extracted for pooled analyses. Subgroup analysis, sensitivity analysis and meta-regression were performed to explore the sources of heterogeneity.

Results: Seven articles containing eight studies with 2503 patients were enrolled. The results from the pooled analyses showed that the VDR expression generally had no relationship with BC patients' overall survival (OS), disease-free survival (DFS), cancer-specific survival (CSS), and progression-free survival (PFS) $(P>0.05)$. Because only the number of studies exploring the relationship between VDR expression and OS is greater than five and there is heterogeneity, we explored the sources of heterogeneity of these studies. Subgroup analyses showed that the VDR expression in the nucleus had no relationship with OS, but high total VDR expression in the nucleus and cytoplasm was related to a better OS (pooled $\mathrm{HR}=0.41 ; 95 \% \mathrm{Cl}=0.18-0.95 ; P=0.038$ ). In addition, in subgroup of studies using cut-off values other than 'immunoreactive score $(\mathrm{IRS})>5$ ' and 'IRS $>25$ ', high VDR expression was associated with a better OS (pooled $\mathrm{HR}=0.47 ; 95 \% \mathrm{Cl}=0.30-0.74 ; P=0.001$ ). Sensitivity analysis showed that the result pattern was not obviously affected by any single study. Meta-regression showed that the source of heterogeneity was not country $(P=0.657)$, pathological type $(P=0.614)$, molecular type $(P=0.423)$, staining location $(P=0.481)$, or cut-off value $(P=0.509)$.

\footnotetext{
* Correspondence: shiscar@163.com; yclvwenping@163.com

${ }^{\dagger}$ Haiyan Xu and Zhenhua Liu contributed equally to this work.

${ }^{3}$ Department of Radiotherapy, The Third People's Hospital of Yancheng, 75 Juchang Street, Yancheng 224005, China

${ }^{4}$ Department of Oncology, The Third People's Hospital of Yancheng, 75

Juchang Street, Yancheng 224005, China

Full list of author information is available at the end of the article
}

(c) The Author(s). 2020 Open Access This article is licensed under a Creative Commons Attribution 4.0 International License, which permits use, sharing, adaptation, distribution and reproduction in any medium or format, as long as you give appropriate credit to the original author(s) and the source, provide a link to the Creative Commons licence, and indicate if changes were made. The images or other third party material in this article are included in the article's Creative Commons licence, unless indicated otherwise in a credit line to the material. If material is not included in the article's Creative Commons licence and your intended use is not permitted by statutory regulation or exceeds the permitted use, you will need to obtain permission directly from the copyright holder. To view a copy of this licence, visit http://creativecommons.org/licenses/by/4.0/. The Creative Commons Public Domain Dedication waiver (http://creativecommons.org/publicdomain/zero/1.0/) applies to the data made available in this article, unless otherwise stated in a credit line to the data. 
(Continued from previous page)

Conclusions: The protein expression level of VDR in entire BC cells evaluated by immunohistochemistry is related to the $O S$ of $B C$ patients. It is expected that a more individualized vitamin D intake and a more accurate prognosis assessment can be recommended for BC patients based on the VDR expression. Of course, more preclinical and clinical studies are needed.

Keywords: Breast cancer, Vitamin D receptor, Prognosis, Meta-analysis

\section{Background}

The global incidence of breast cancer (BC) has been on the rise since the late 1970s, seriously threatening women's health [1]. According to statistics [2], there were 2.088 million new cases of $\mathrm{BC}$ in the world in 2018, and the incidence of $\mathrm{BC}$ in developed countries was significantly higher than that in developing countries. $\mathrm{BC}$ has become one of the most common malignant tumors that causes female death [3]. In the past few decades, despite improvements in surgical techniques and changes in chemotherapy and radiotherapy methods, the mortality rate of $\mathrm{BC}$ has significantly decreased, but the prognosis of $\mathrm{BC}$ patients is still not satisfactory [4]. Previous meta-analyses have supported an inverse association between vitamin $\mathrm{D}$ status/intake and $\mathrm{BC}$ occurrence $[5,6]$, and an association of low levels of vitamin $\mathrm{D}$ with increased risk of recurrence and death in BC patients $[7,8]$.

Vitamin $\mathrm{D}$ is a steroid hormone in structure, and its metabolic active substance is $1,25(\mathrm{OH})_{2} \mathrm{D}_{3}$, which plays an important role in calcium and phosphorus metabolism. Preclinical studies have found that $1,25(\mathrm{OH})_{2} \mathrm{D}_{3}$ can inhibit the proliferation of $\mathrm{BC}$ cell lines and promote their differentiation and apoptosis [9, 10]. Moreover, findings from a prospective study including 10,578 premenopausal and 20,909 postmenopausal women suggested that higher intakes of calcium and vitamin D may reduce the risk of $\mathrm{BC}$ in premenopausal women [11]. Therefore, in our clinical work, we suggest that early $\mathrm{BC}$ patients and premenopausal women should appropriately increase their vitamin $\mathrm{D}$ intake. However, it seems inappropriate to recommend that each patient take the same dose of vitamin $\mathrm{D}$, because vitamin $\mathrm{D}$ as a ligand for its biological function depends on binding to the receptor, while the vitamin D receptor (VDR) is expressed vary in different patients. Therefore, we established a scientific hypothesis that the vitamin $\mathrm{D}$ intakes of $\mathrm{BC}$ patients should refer to their VDR expression levels. To prove this hypothesis, we first need to verify the correlation between the VDR expression and the prognosis of $\mathrm{BC}$ patients.

VDR is a ligand-dependent transcriptional regulator protein and a member of the nuclear receptor superfamily [12, 13]. In the breast epithelium, vitamin D interacts with VDR in the same place or in adjacent cells to maintain differentiation and quiescence [14]. A case-control study by Hemida et al. showed that VDR expression was upregulated in $\mathrm{BC}$ tissues and correlated with estrogen receptor alpha (ER- $\alpha$ ) expression [15]. Retrospective studies by Heublein [16] and Huss [17] et al. showed that low expression of VDR is an indicator for poor prognosis of BC. However, there are certain differences between the various studies, and the sample size of the studies is small, so the relevant results cannot directly and effectively guide clinical work. In view of this, a meta-analysis was carried out by collecting literatures on VDR expression in $\mathrm{BC}$ to clarify the relationship between VDR expression and the prognosis of $\mathrm{BC}$ patients.

\section{Methods \\ Search strategy}

The following databases were retrieved to find literatures: PubMed, Embase, and the Cochrane Library (last update by May 20, 2020). There were no language restrictions for literature collection. 'Receptors, calcitriol' and 'breast neoplasms' were the Medical Subject Heading $(\mathrm{MeSH})$ terms. Each retrieved literature was read throughout.

\section{Inclusion criteria}

- Studies investigated the prognostic role of VDR in $\mathrm{BC}$.

- Studies provided the hazard ratio (HR) and $95 \%$ confidence intervals (CI) of VDR or the survival curves.

- The patients did not receive neoadjuvant radiotherapy or chemotherapy before surgery.

\section{Exclusion criteria}

- Reviews, letters, case reports, animal trials and conference abstracts.

- Studies with small sample size $(<50)$.

- Only the complete or most recent study was enrolled if one patient cohort were researched by multiple studies. 


\section{Data extraction}

Some important parameters extracted from the included studies have been showed in the Table 1 . If the article reports both univariate analysis results and multivariate analysis results, the latter will be adopted because it reduces the interference of confounding factors.

\section{Guidelines and quality assessment}

This meta-analysis complied with the Systematic Reviews and Meta-Analyses (PRISMA) guidelines [23]. The quality assessment of the studies followed the Newcastle-Ottawa Quality Assessment Scale (NOS). The lowest NOS score is 0 and the highest is 9. A score of 6 or more indicates high quality of the study.

\section{Statistical analysis}

When the article did not directly report HR and 95\% CI and only provided Kaplan-Meier survival curves, we indirectly extracted HR and 95\% CI from the curves according to Tierney' method [24]. The $P$ value of chisquare test $<0.05$ and/or $I^{2} \geq 25 \%$ indicated heterogeneity, then the random-effects model (the DerSimonianLaird method) was used [25], otherwise the fixed-effects model (the Mante-Haenszel method) was used [26]. If there is heterogeneity, subgroup analysis, sensitivity analysis and meta-regression will be performed to explore the sources of heterogeneity. The STATA version 12.0 (Stata Corporation, College Station, TX, USA) was used to analysis data and generate figures. Except estimating heterogeneity and publication bias, a $P$ value less than 0.05 was considered significant.

\section{Results}

\section{Study characteristics}

Summarizing the search results of the three databases, 307 articles were initially screened out. Then 298 articles were excluded because their content did not include the prognostic value of VDR in BC. We read the full text of the remaining nine articles. We found that two remaining articles investigated the relationship between VDR mRNA expression and prognosis of BC patients. Since the data in these two articles came from public databases and was duplicated, they were excluded. Finally, seven articles containing eight studies with 2503 patients were included in this meta-analysis (Fig. 1) [16-22]. The article by Zehni et al. [22] contains two subgroup studies. The mean score of NOS for the eight studies was 7.25 , ranging from 6 to 8 (Table 1). VDR expression was detected using immunohistochemistry (IHC) in all included studies.

Table 1 showed the important parameters of included studies. Patients came from five countries: Germany, Sweden, America, Yugoslavia or Japan. The number of patients in each study ranged from 82 to 1114 . Patients in most included studies had multiple pathological types and molecular types. Four studies investigated the prognostic role of intranuclear VDR expression. Two studies investigated the prognostic role of total VDR expression in nucleus and cytoplasm. Four studies used immunoreactive score (IRS) to assess the protein expression of VDR. HRs for overall survival (OS) were extracted in six studies, five of which were reported directly. HRs for disease-free survival (DFS) were extracted in five studies, three of which were reported directly. HRs for cancerspecific survival (CSS) were reported directly in two studies. Only one study investigated patients' progression-free survival (PFS).

\section{Overall survival}

Five articles containing six studies with 1681 patients investigated the relationship between VDR expression and patients' $\mathrm{OS}$ in $\mathrm{BC}$. Because the heterogeneity of these six studies existed $\left(I^{2}=69.2 \%, P=0.006\right)$, a randomeffects model was used. The results of pooled analyses were showed in Table 2. In general, the VDR expression had no relationship with $\mathrm{BC}$ patients' $\mathrm{OS}$ (pooled $\mathrm{HR}=$ 0.82; 95\% CI $=0.64-1.06 ; P=0.052$ ) (Fig. 2). Because the number of these studies is greater than five, we explored the sources of heterogeneity.

The results of subgroup analyses showed that in different subgroups divided by patients' country, pathological type and molecular type, VDR expression remained unrelated to $\mathrm{BC}$ patients' $\mathrm{OS}(P>0.05$, Table 2$)$. However, in subgroups divided by staining location and cut-off value, positive results were observed. The VDR expression in the nucleus had no relationship with OS, but high total VDR expression in nucleus and cytoplasm was related to better OS (pooled $\mathrm{HR}=0.41 ; 95 \% \mathrm{CI}=0.18-$ $0.95 ; P=0.038$ ) (Table 2; Fig. 3 ). In subgroup of studies using cut-off values other than 'IRS $>5$ ' and 'IRS $>25$ ', high VDR expression was associated with better OS (pooled HR $=0.47 ; 95 \% \mathrm{CI}=0.30-0.74 ; P=0.001$ ) (Table 2; Fig. 4).

Sensitivity analysis using a random-effects model showed that the result pattern was not obviously affected by any single study (Fig. 5). Meta-regression showed that the source of heterogeneity was not country $(P=0.657)$, pathological type $(P=0.614)$, molecular type $(P=0.423)$, staining location $(P=0.481)$, or cut-off value $(P=0.509)$.

There was a publication bias because the funnel plot was asymmetrical (Fig. 6). The "Trim and Fill" method under a random-effects model was used to eliminate the publication bias [27]. After eliminating the publication bias, the VDR expression was still not related to $\mathrm{BC}$ patients' OS in general (corrected pooled $\mathrm{HR}=0.82 ; 95 \%$ $\mathrm{CI}=0.64-1.06 ; P=0.127)$. 


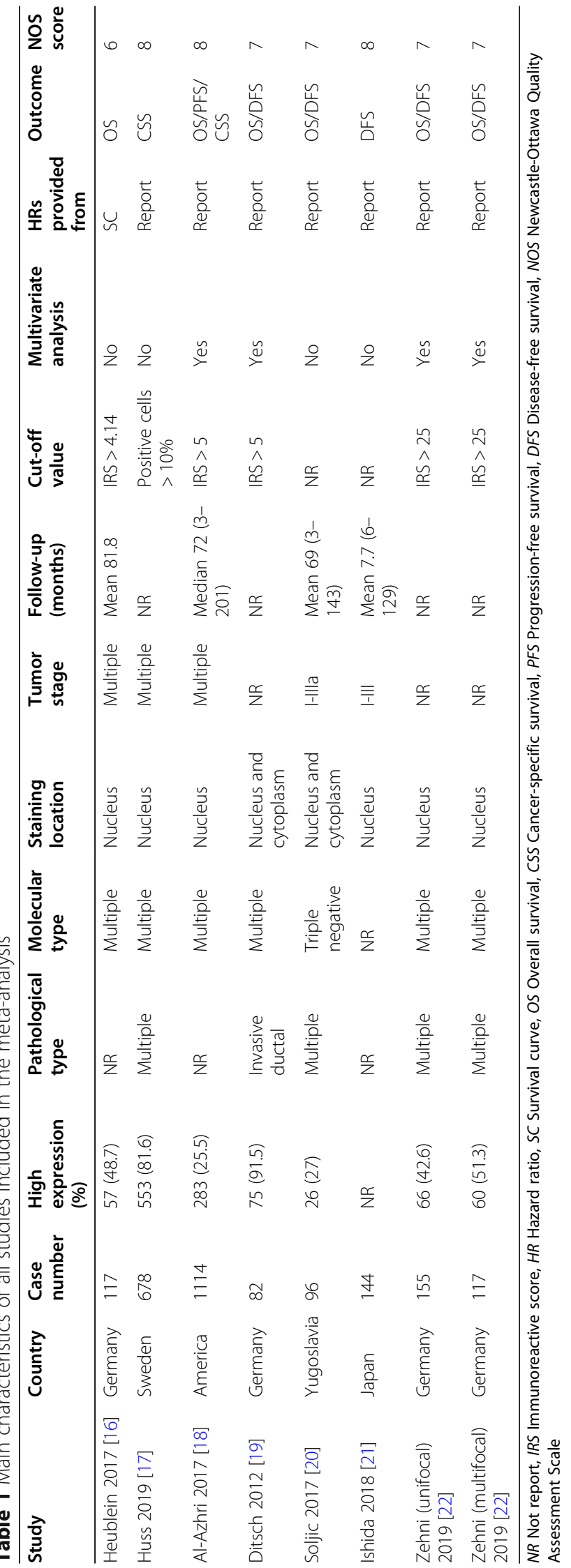




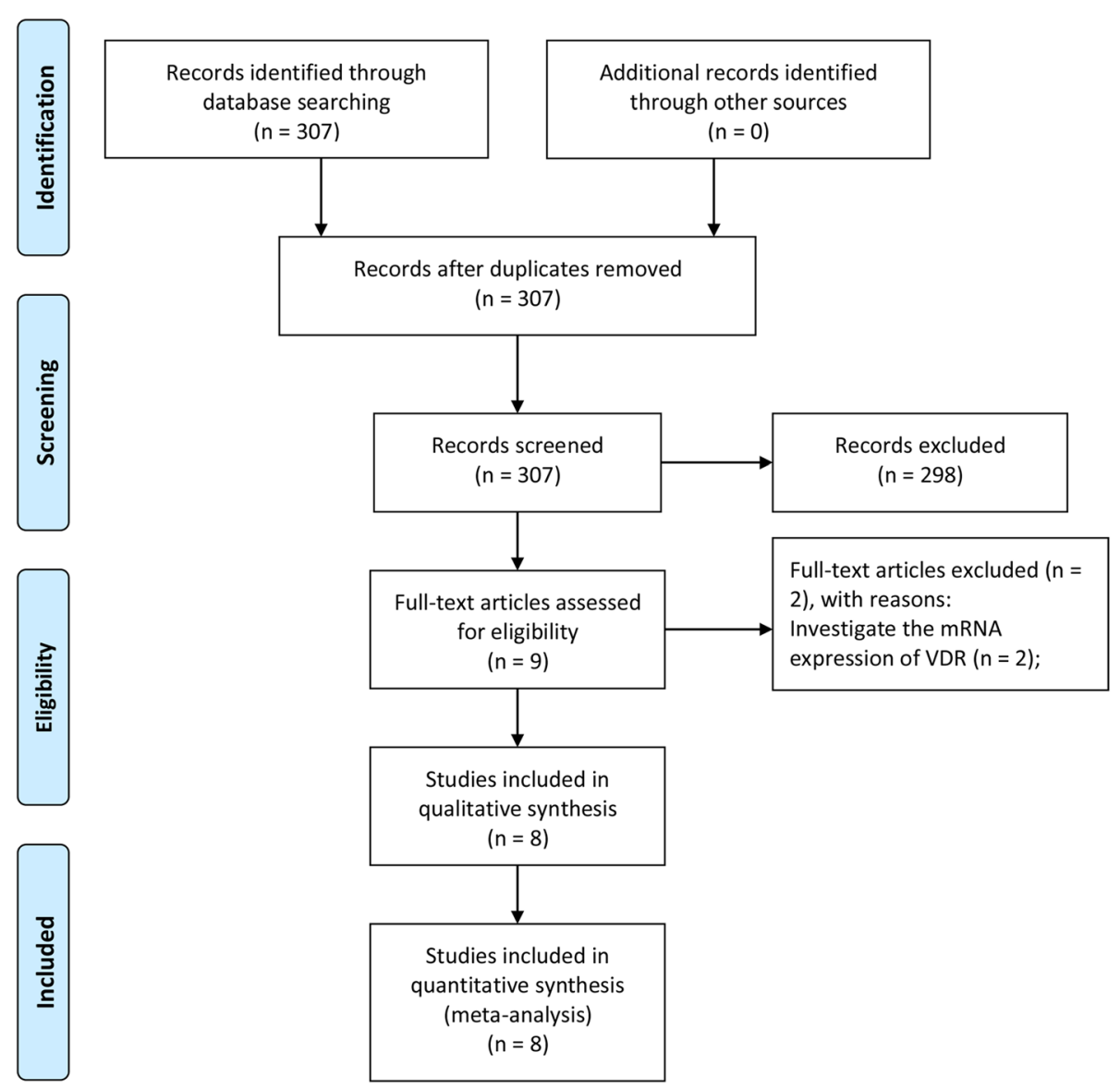

Fig. 1 Flow diagram of the study selection process for the meta-analysis

\section{Disease-free survival}

Four articles containing five studies with 594 patients investigated the relationship between VDR expression level and patients' DFS in BC. Because the heterogeneity of these five studies existed $\left(I^{2}=72.7 \%, P=0.005\right)$, a random-effects model was used. The pooled result showed that there was no relationship between VDR expression and patients' DFS (pooled $\mathrm{HR}=1.11$; 95\% CI = 0.73-1.70; $P=0.625$ ) (Table 2; Fig. 7).

\section{Cancer-specific survival}

Two studies with 1792 patients investigated the relationship between VDR expression level and patients' CSS in BC. Because the heterogeneity of these two studies existed $\left(I^{2}=73.4 \%, P=0.052\right)$, a random-effects model was used. The pooled result showed that there was no relationship between VDR expression and patients' CSS (pooled HR $=0.78 ; 95 \%$ CI $=0.42-1.46 ; P=0.439)$ (Table 2).

\section{Progression-free survival}

Only one study containing 1114 patients investigated the relationship between VDR expression and patients' PFS in BC. There was no relationship between VDR expression and patients' PFS $(\mathrm{HR}=1.14 ; 95 \% \mathrm{CI}=0.87-1.50)$ (Table 2).

\section{Discussion}

It has been reported that vitamin $\mathrm{D}$ can be regarded as a protective factor for reducing the risk of various cancers including $\mathrm{BC}$, and can inhibit the cell proliferation of normal and malignant breast cells [28], and induce cell differentiation and apoptosis [29]. Vitamin D is involved in the process of regulating cell growth, differentiation, and apoptosis by binding to VDR [30]. VDR is a nuclear receptor that regulates gene expression and is expressed in 80 to $90 \%$ of BC patients [31]. VDR can be expressed in breast epithelial cells, which suggests that vitamin $\mathrm{D}$ may directly affect the sensitivity of the glands. In vitro studies have shown that the VDR ligand, $1,25(\mathrm{OH})_{2} \mathrm{D}_{3}$, is involved in maintaining the differentiation of breast cells. Knocking out the VDR gene increases the susceptibility of $\mathrm{BC}$ in mice. The expression of VDR is downregulated in invasive $B C$ [30], suggesting that the expression of VDR is negatively correlated with the progress of $\mathrm{BC}$, and the expression of VDR has a certain protective 
Table 2 The pooled associations between VDR expression and the prognosis of patients with breast cancer

\begin{tabular}{|c|c|c|c|c|c|c|}
\hline \multirow[t]{2}{*}{ Outcome subgroup } & \multirow{2}{*}{$\begin{array}{l}\text { Study } \\
\text { number }\end{array}$} & \multirow{2}{*}{$\begin{array}{l}\text { Case } \\
\text { number }\end{array}$} & \multirow[t]{2}{*}{ HR $(95 \% \mathrm{Cl})$-model } & \multirow{2}{*}{$\begin{array}{l}P \\
\text { value }\end{array}$} & \multicolumn{2}{|c|}{ Heterogeneity } \\
\hline & & & & & $I^{2}(\%)$ & $P$ \\
\hline OS & 6 & 1681 & 0.82 (0.64-1.06)-random & 0.052 & 69.2 & 0.006 \\
\hline \multicolumn{7}{|l|}{ Country } \\
\hline Germany & 4 & 471 & $0.80(0.58-1.10)-$ random & 0.161 & 763 & 0.005 \\
\hline Others & 2 & 1210 & 0.71 (0.27-1.88)-random & 0.488 & 70.7 & 0.065 \\
\hline \multicolumn{7}{|l|}{ Pathological type } \\
\hline Invasive ductal & 1 & 82 & $0.49(0.12-1.97)$ & 0.315 & - & - \\
\hline Others & 5 & 1599 & $0.83(0.64-1.08)-$ random & 0.168 & 74.1 & 0.004 \\
\hline \multicolumn{7}{|l|}{ Molecular type } \\
\hline Triple negative & 1 & 96 & $0.37(0.13-1.08)$ & 0.066 & - & - \\
\hline Multiple & 5 & 1585 & 0.85 (0.67-1.10)-random & 0.229 & 70.1 & 0.010 \\
\hline \multicolumn{7}{|l|}{ Staining location } \\
\hline Nucleus & 4 & 1503 & 0.87 (0.68-1.12)-random & 0.293 & 76.1 & 0.006 \\
\hline Nucleus and cytoplasm & 2 & 178 & $0.41(0.18-0.95)$-fixed & 0.038 & 0 & 0.753 \\
\hline \multicolumn{7}{|l|}{ Cut-off value } \\
\hline IRS $>5$ & 2 & 1196 & $0.98(0.67-1.45)$ - fixed & 0.931 & 7.3 & 0.299 \\
\hline $\operatorname{IRS}>25$ & 2 & 272 & 0.94 (0.70-1.26)-random & 0.664 & 82.7 & 0.016 \\
\hline Others & 2 & 213 & 0.47 (0.30-0.74)- fixed & 0.001 & 0 & 0.613 \\
\hline DFS & 5 & 594 & $1.11(0.73-1.70)-$ random & 0.625 & 72.7 & 0.005 \\
\hline CSS & 2 & 1792 & $0.78(0.42-1.46)-$ random & 0.439 & 73.4 & 0.052 \\
\hline PFS & 1 & 1114 & $1.14(0.87-1.50)$ & 0.346 & - & - \\
\hline
\end{tabular}

VDR Vitamin D receptor, OS Overall survival, IRS Immunoreactive score, DFS Disease-free survival, CSS Cancer-specific survival, PFS Progression-free survival, $H R$ Hazard ratio, Cl Confidence interval

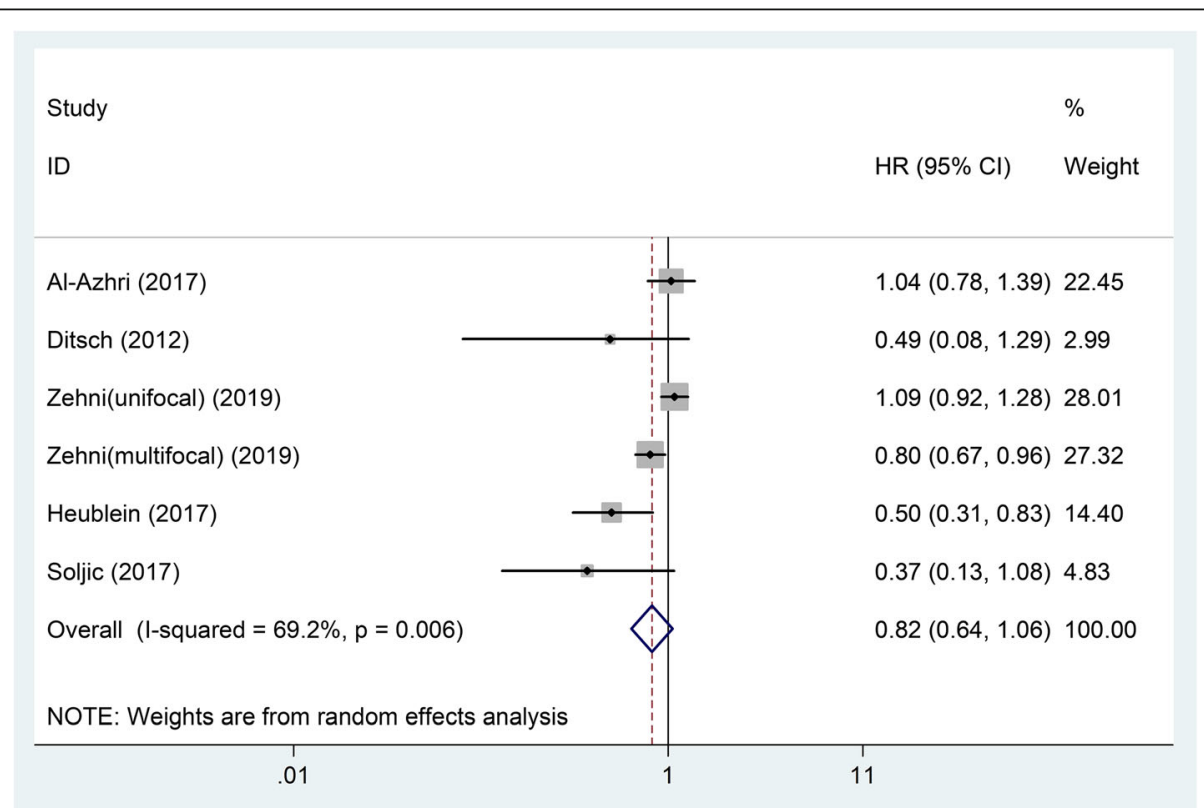

Fig. 2 Forest plot of studies evaluating the hazard ratio of high VDR expression for the overall survival of breast cancer patients. VDR: vitamin D receptor; HR: hazard ratio; Cl: confidence interval 


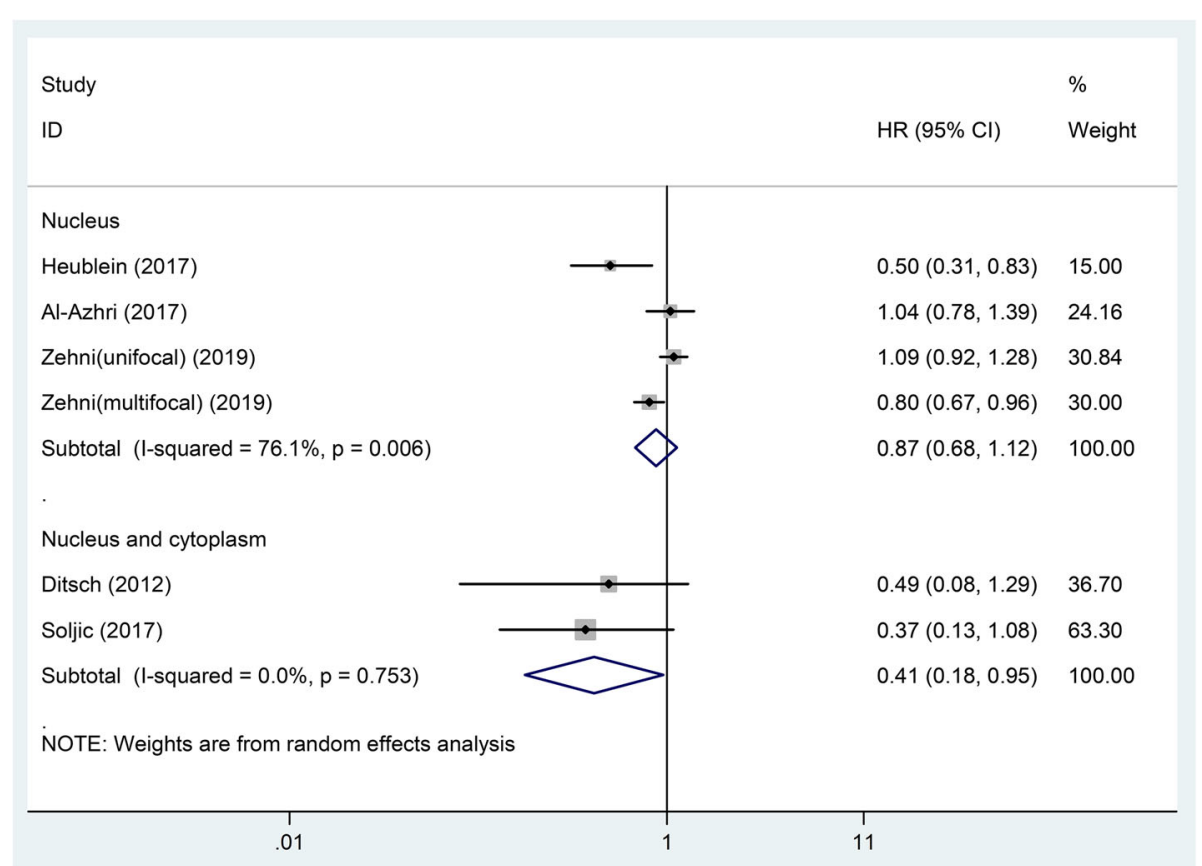

Fig. 3 Forest plot of studies evaluating the hazard ratio of high VDR expression for the overall survival of breast cancer patients stratified by staining location. VDR: vitamin D receptor; HR: hazard ratio; Cl: confidence interval

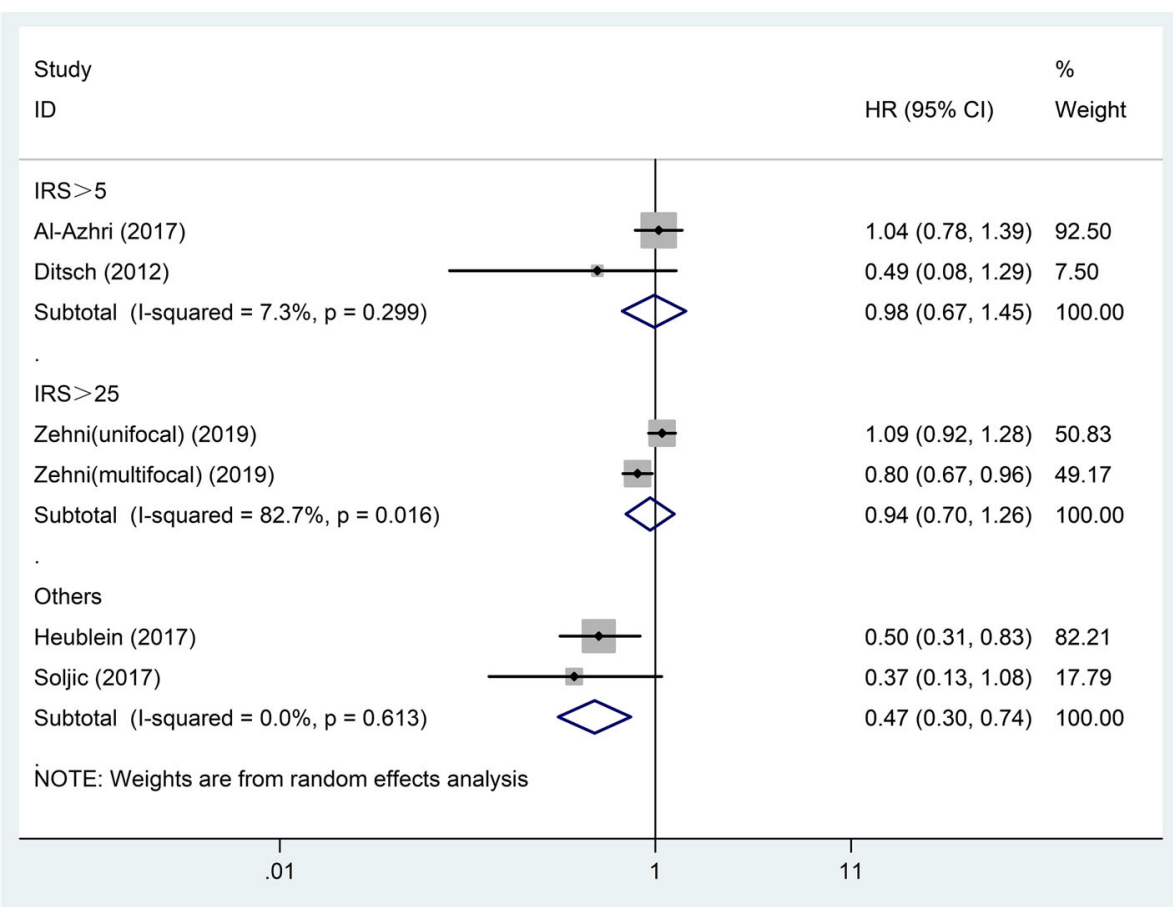

Fig. 4 Forest plot of studies evaluating the hazard ratio of high VDR expression for the overall survival of breast cancer patients stratified by cutoff value. VDR: vitamin D receptor; IRS: immunoreactive score; HR: hazard ratio; Cl: confidence interval 


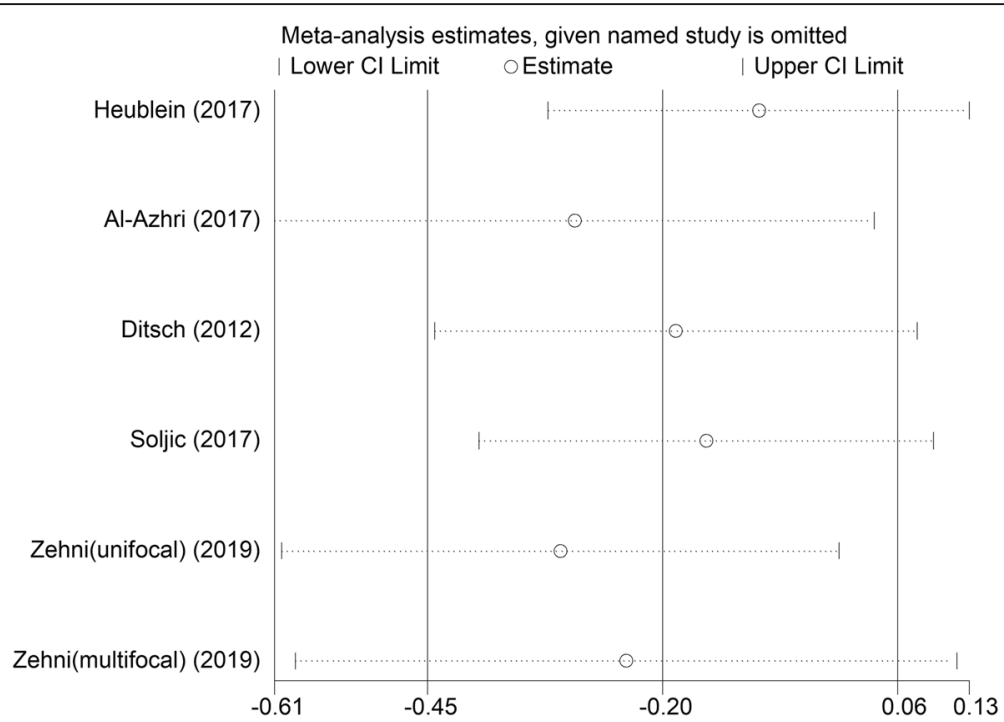

Fig. 5 Sensitivity analysis of studies evaluating the relationship between VDR expression and patients' overall survival in breast cancer. VDR: vitamin D receptor; Cl: confidence interval

effect on the breast. Therefore, in theory, the high expression of VDR in BC should be related to a good prognosis.

In this meta-analysis, we found that the relationship between VDR expression and prognosis in BC was mainly affected by the staining location. Results of the subgroup analysis showed that only the total VDR expression in nucleus and cytoplasm was related to BC patients' survival. VDR mainly functions as a nuclear receptor [32, 33], but it is widely distributed on multiple subcellular structures, including the nucleus, nuclear membrane, cytoplasm, and cell membrane [17]. Our results indicate that VDR in the cytoplasm also exerts specific biological functions in the progression of $\mathrm{BC}$ cells. In view of this, we recommend that when performing immunohistochemical analysis of $\mathrm{BC}$ specimens in clinical work, the total expression of VDR in nucleus and cytoplasm should be detected instead of only the expression of VDR in nucleus.

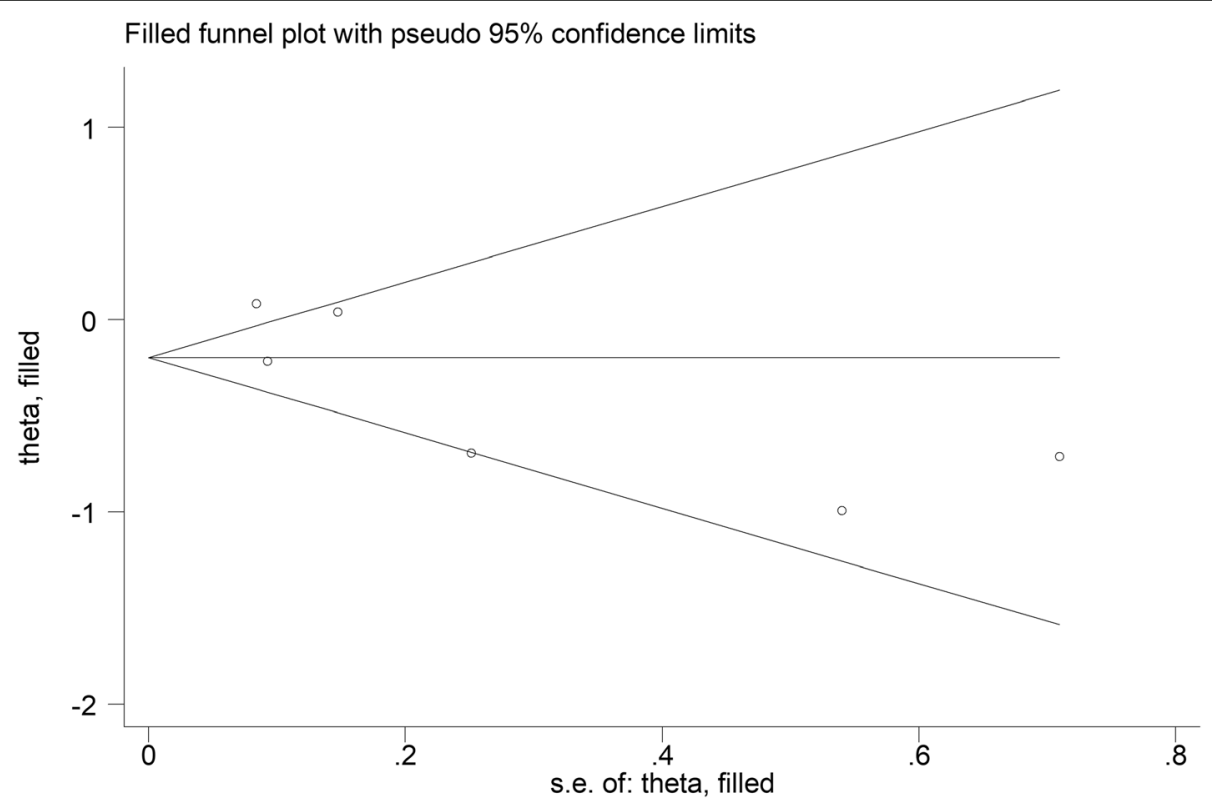

Fig. 6 Funnel plot of publication bias for studies evaluating the relationship between VDR expression and patients' overall survival in breast cancer 


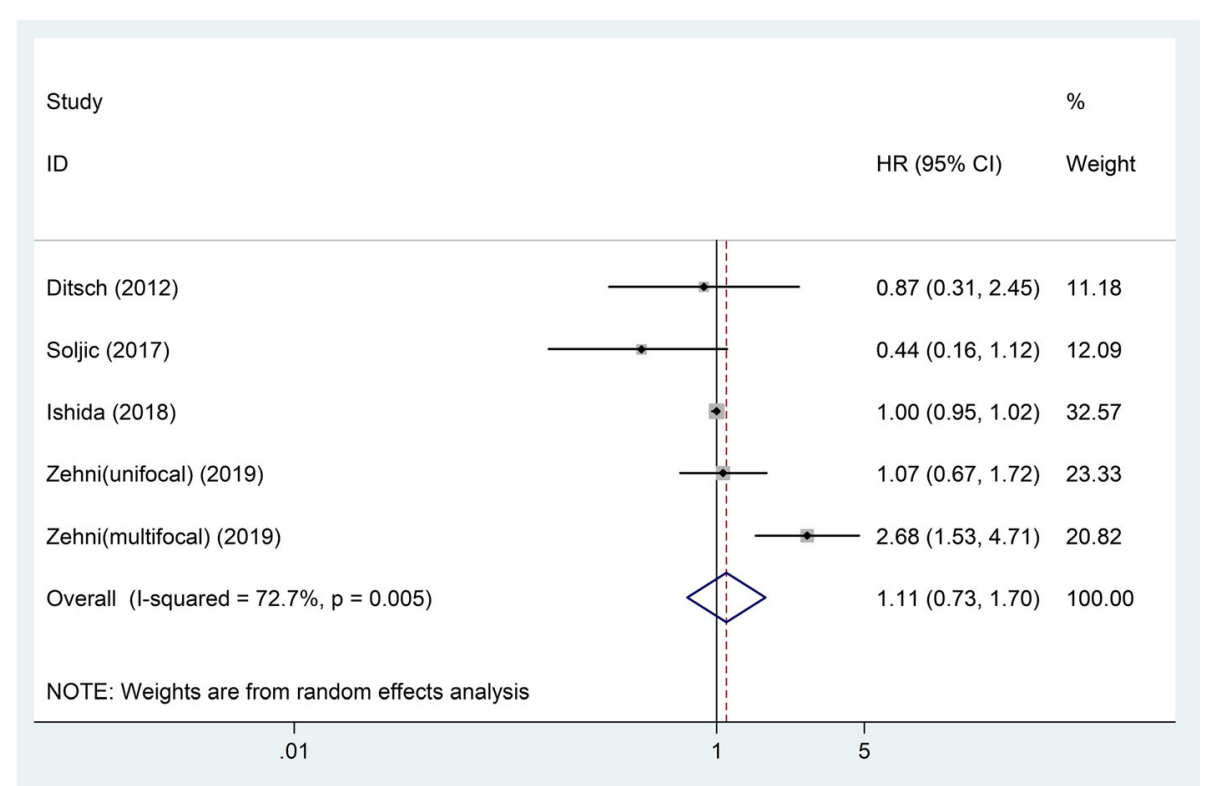

Fig. 7 Forest plot of studies evaluating the hazard ratio of high VDR expression for the disease-specific survival of breast cancer patients. VDR: vitamin D receptor; HR: hazard ratio; Cl: confidence interval

Our study has made it clear that both the serum vitamin D level and the expression of VDR are related to the prognosis of $\mathrm{BC}$ patients, which suggests that the serum vitamin $\mathrm{D}$ level of different $\mathrm{BC}$ patients should be adjusted according to the expression of VDR. BC patients with high total VDR expression in nucleus and cytoplasm may not need too much vitamin D intake. Of course, this hypothesis needs to be further verified by controlled clinical trials with larger sample sizes. In addition, our results are also conducive to more accurate assessment of the prognosis of $\mathrm{BC}$ patients, which is important for formulating appropriate treatment plans.

At present, Tumor Node Metastasis (TNM) staging is the most important indicator for assessing the prognosis of $\mathrm{BC}$ patients, but the accuracy of prediction is reduced due to individual differences. It is well known that patients with same TNM staging may have different prognosis. Therefore, an effective biological indicator is urgently needed to help assess the prognosis of $\mathrm{BC}$ patients [20]. Although serum vitamin D level and VDR expression are both related to the prognosis of $\mathrm{BC}$ patients [7, 11], VDR expression seems a more suitable prognostic indicator of $\mathrm{BC}$ because serum vitamin $\mathrm{D}$ level fluctuates greatly due to diet and sunlight exposure.

In addition to the prognostic value of VDR protein expression, the prognostic value of VDR mRNA expression in $\mathrm{BC}$ has also been reported [34, 35]. Murray et al. [34] evaluated a pooled database of 12 publicly available BC datasets $(n=2592$ patients $)$ containing gene expression data, then found that the mRNA expression of VDR was not related to the DFS of BC patients as a whole. In this meta-analysis, we found that the protein expression of VDR was also not related to the DFS of $\mathrm{BC}$ patients. This suggests that the mRNA expression and the protein expression of VDR may be consistent. However, there is still a lack of reports on the relationship between VDR mRNA expression and OS of BC patients. The correlation between VDR polymorphism and $\mathrm{BC}$ has also been researched in previous studies [36-38]. Raimondi et al. reported that the polymorphism of the third gene Bsml and fifth gene Fokl of the VDR gene may be able to regulate the risk of $\mathrm{BC}$ [39]. A high-quality meta-analysis showed that the Fokl polymorphism of the VDR gene was associated with an increased risk of BC [37]. However, another meta-analysis by $\mathrm{Lu}$ et al. showed that VDR polymorphism (Fok1, Bsm1, Taq1, and Apa1) were not associated with the risk of $\mathrm{BC}$ in general population [36]. The roles of VDR mRNA expression and polymorphism in $\mathrm{BC}$ need to be further explored by more prospective clinical studies.

Our meta-analysis is the first to study the relationship between VDR protein expression level and $\mathrm{BC}$ prognosis. Although only 8 studies were included, the present meta-analysis based on the data of 2503 patients can still provide some help and reference for assessing the prognostic role of VDR expression in BC. Of course, the small number of included studies may affect the reliability of the results of the subgroup analysis. In addition, this meta-analysis also has some other shortcomings. For example, part of the HRs is obtained from univariate analyses, which will overestimate the effect size because 
the influence of confounding factors is not excluded. The clinical information provided by the included studies is inadequate. Some studies did not provide the pathological and molecular types of patients, which prevented us from performing high-quality subgroup analyses based on these clinical features, leading to the omission of some valuable positive results. Furthermore, some HRs were estimated based on survival curves, which caused statistical errors.

\section{Conclusion}

Previous meta-analyses have shown an inverse association between serum vitamin $\mathrm{D}$ level and $\mathrm{BC}$ prognosis. Similarly, VDR expression is also related to the prognosis of BC patients. Our review and meta-analysis demonstrated that $\mathrm{BC}$ patients with high total VDR expression in nucleus and cytoplasm had better OS. This is an important finding in terms of future randomized controlled trials which might reveal a directive function of VDR expression for the adjustment of vitamin $\mathrm{D}$ intake in $\mathrm{BC}$ patients. VDR expression is not affected by diet and sunlight exposure, so it is more suitable for assessing the prognosis of $\mathrm{BC}$ than the serum vitamin $\mathrm{D}$ level. A more accurate assessment of the prognosis by combining TNM staging and VDR expression is conducive to formulating a more appropriate treatment plan for $\mathrm{BC}$ patients. VDR expression is expected to become a routine immunohistochemical examination item in the pathological diagnosis of $\mathrm{BC}$.

\section{Abbreviations}

BC: Breast cancer; VDR: Vitamin D receptor; MeSH: Medical Subject Heading; IHC: Immunohistochemistry; HR: Hazard ratio; Cl: Confidence intervals; TNM: Tumor Node Metastasis; NOS: Newcastle-Ottawa Quality Assessment Scale; IRS: Immunoreactive score; OS: Overall survival; DFS: Disease-free survival; CSS: Cancer-specific survival; PFS: Progression-free survival

\section{Acknowledgements}

Not applicable.

\section{Authors' contributions}

HTS and CBW conceived and designed the study. HYX and ZHL performed the analysis, prepared the figures and tables and wrote the main manuscript. All of the authors reviewed the manuscript. The author(s) read and approved the final manuscript.

\section{Funding}

Not applicable.

\section{Availability of data and materials}

Meta-analysis is a secondary analysis, which the data are all fully available without restriction, and all the material can be found in the included original studies.

\section{Ethics approval and consent to participate}

All analyses were based on previous published studies, thus no ethical approval and patient consent are required.

\section{Consent for publication}

Not applicable.

\section{Competing interests}

The authors declare that they have no conflicts of interest concerning this article.

\section{Author details}

'Department of Medical Oncology, The Second People's Hospital of Lianyungang, 41 Hailian Road, Lianyungang 222000, China. 'Department of Radiotherapy, The First People's Hospital of Yancheng, 66 Renmin Street, Yancheng 224005, China. 'Department of Radiotherapy, The Third People's Hospital of Yancheng, 75 Juchang Street, Yancheng 224005, China.

${ }^{4}$ Department of Oncology, The Third People's Hospital of Yancheng, 75 Juchang Street, Yancheng 224005, China.

Received: 18 June 2020 Accepted: 22 October 2020

Published online: 01 November 2020

\section{References}

1. Global Burden of Disease Cancer C, Fitzmaurice C, Dicker D, Pain A, Hamavid H, Moradi-Lakeh M, MF MI, Allen C, Hansen G, Woodbrook R, et al. The global burden of Cancer 2013. JAMA Oncol. 2015;1(4):505-27.

2. Bray F, Ferlay J, Soerjomataram I, Siegel RL, Torre LA, Jemal A. Global cancer statistics 2018: GLOBOCAN estimates of incidence and mortality worldwide for 36 cancers in 185 countries. CA Cancer J Clin. 2018;68(6):394-424.

3. Siegel RL, Miller KD, Jemal A. Cancer statistics, 2017. CA Cancer J Clin. 2017; 67(1):7-30.

4. Ferlay J, Colombet M, Soerjomataram I, Mathers C, Parkin DM, Pineros M, Znaor A, Bray F. Estimating the global cancer incidence and mortality in 2018: GLOBOCAN sources and methods. Int J Cancer. 2019;144(8):1941-53.

5. Hossain S, Beydoun MA, Beydoun HA, Chen X, Zonderman AB, Wood RJ. Vitamin D and breast cancer: a systematic review and meta-analysis of observational studies. Clin Nutr ESPEN. 2019;30:170-84.

6. Estebanez N, Gomez-Acebo I, Palazuelos C, Llorca J, Dierssen-Sotos T. Vitamin D exposure and risk of breast Cancer: a meta-analysis. Sci Rep. 2018;8(1):9039.

7. Rose AA, Elser C, Ennis M, Goodwin PJ. Blood levels of vitamin D and early stage breast cancer prognosis: a systematic review and meta-analysis. Breast Cancer Res Treat. 2013;141(3):331-9.

8. Hu K, Callen DF, Li J, Zheng H. Circulating vitamin D and overall survival in breast Cancer patients: a dose-response meta-analysis of cohort studies. Integr Cancer Ther. 2018;17(2):217-25.

9. So JY, Lee HJ, Smolarek AK, Paul S, Wang CX, Maehr H, Uskokovic M, Zheng $X$, Conney AH, Cai L, et al. A novel Gemini vitamin D analog represses the expression of a stem cell marker CD44 in breast cancer. Mol Pharmacol. 2011;79(3):360-7.

10. Verma A, Cohen DJ, Schwartz N, Muktipaty C, Koblinski JE, Boyan BD, Schwartz Z. 24R,25-Dihydroxyvitamin D3 regulates breast cancer cells in vitro and in vivo. Biochim Biophys Acta Gen Subj. 2019;1863(10):1498-512.

11. Dizdar O, Harputluoglu H, Altundag K. Vitamin D intake and breast cancer risk in postmenopausal women. Arch Intern Med. 2007;167(22):2532 author reply 2532.

12. Zheng W, Cao L, Ouyang L, Zhang Q, Duan B, Zhou W, Chen S, Peng W, Xie $Y$, Fan $Q$, et al. Anticancer activity of 1,25-(OH)2D3 against human breast cancer cell lines by targeting Ras/MEK/ERK pathway. OncoTargets Ther. 2019;12:721-32.

13. Gandini S, Gnagnarella P, Serrano D, Pasquali E, Raimondi S. Vitamin D receptor polymorphisms and cancer. Adv Exp Med Biol. 2014;810:69-105.

14. Welsh J. Vitamin D metabolism in mammary gland and breast cancer. Mol Cell Endocrinol. 2011;347(1-2):55-60.

15. Hemida MA, AbdEImoneim NA, Hewala TI, Rashad MM, Abdaallah S. Vitamin $D$ receptor in breast Cancer tissues and its relation to estrogen receptor alpha (ER-alpha) gene expression and serum 25-hydroxyvitamin D levels in Egyptian breast Cancer patients: a case-control study. Clin Breast Cancer. 2019;19(3):e407-14.

16. Heublein S, Mayr D, Meindl A, Kircher A, Jeschke U, Ditsch N. Vitamin D receptor, retinoid $X$ receptor and peroxisome proliferator-activated receptor gamma are overexpressed in BRCA1 mutated breast cancer and predict prognosis. J Exp Clin Cancer Res. 2017;36(1):57.

17. Huss L, Butt ST, Borgquist S, Elebro K, Sandsveden M, Rosendahl A, Manjer J. Vitamin D receptor expression in invasive breast tumors and breast cancer survival. Breast Cancer Res. 2019;21(1):84.

18. Al-Azhri J, Zhang Y, Bshara W, Zirpoli G, McCann SE, Khoury T, Morrison CD, Edge SB, Ambrosone CB, Yao S. Tumor expression of vitamin D receptor 
and breast Cancer Histopathological characteristics and prognosis. Clin Cancer Res. 2017;23(1):97-103.

19. Ditsch N, Toth B, Mayr D, Lenhard M, Gallwas J, Weissenbacher T, Dannecker C, Friese $\mathrm{K}$, Jeschke $\mathrm{U}$. The association between vitamin $\mathrm{D}$ receptor expression and prolonged overall survival in breast cancer. J Histochem Cytochem. 2012;60(2):121-9.

20. Soljic M, Mrklic I, Tomic S, Omrcen T, Sutalo N, Bevanda M, Vrdoljak E. Prognostic value of vitamin D receptor and insulin-like growth factor receptor 1 expression in triple-negative breast cancer. J Clin Pathol. 2018;71(1):34-9.

21. Ishida N, Baba M, Hatanaka Y, Hagio K, Okada H, Hatanaka KC, Togashi K, Matsuno Y, Yamashita H. PIK3CA mutation, reduced AKT serine 473 phosphorylation, and increased ERalpha serine 167 phosphorylation are positive prognostic indicators in postmenopausal estrogen receptor-positive early breast cancer. Oncotarget. 2018;9(25):17711-24.

22. Zati Zehni A, Jacob SN, Mumm JN, Heidegger HH, Ditsch N, Mahner S, Jeschke U, Vilsmaier T. Hormone Receptor Expression in Multicentric/ Multifocal versus Unifocal Breast Cancer: Especially the VDR Determines the Outcome Related to Focality. Int J Mol Sci. 2019;20(22):5740.

23. Liberati A, Altman DG, Tetzlaff J, Mulrow C, Gotzsche PC, loannidis JP, Clarke M, Devereaux PJ, Kleijnen J, Moher D. The PRISMA statement for reporting systematic reviews and meta-analyses of studies that evaluate health care interventions: explanation and elaboration. J Clin Epidemiol. 2009;62(10):e1-34.

24. Tierney JF, Stewart LA, Ghersi D, Burdett S, Sydes MR. Practical methods for incorporating summary time-to-event data into meta-analysis. Trials. 2007;8:16.

25. DerSimonian R, Laird N. Meta-analysis in clinical trials. Control Clin Trials. 1986;7(3):177-88

26. Mantel N, Haenszel W. Statistical aspects of the analysis of data from retrospective studies of disease. J Natl Cancer Inst. 1959;22(4):719-48.

27. Duval S, Tweedie R. Trim and fill: a simple funnel-plot-based method of testing and adjusting for publication bias in meta-analysis. Biometrics. 2000;56(2):455-63.

28. Crew KD, Gammon MD, Steck SE, Hershman DL, Cremers S, Dworakowski E, Shane E, Terry MB, Desai M, Teitelbaum SL, et al. Association between plasma 25hydroxyvitamin D and breast cancer risk. Cancer Prev Res. 2009;2(6):598-604.

29. O'Brien KM, Sandler DP, Xu Z, Kinyamu HK, Taylor JA, Weinberg CR. Vitamin D, DNA methylation, and breast cancer. Breast Cancer Res. 2018;20(1):70.

30. Trivedi T, Zheng Y, Fournier PGJ, Murthy S, John S, Schillo S, Dunstan CR, Mohammad KS, Zhou H, Seibel MJ, et al. The vitamin D receptor is involved in the regulation of human breast cancer cell growth via a ligandindependent function in cytoplasm. Oncotarget. 2017:8(16):26687-701.

31. Singh T, Adams BD. The regulatory role of miRNAs on VDR in breast cancer. Transcription. 2017;8(4):232-41.

32. Zhang YG, Lu R, Wu S, Chatterjee I, Zhou D, Xia Y, Sun J. Vitamin D receptor protects against dysbiosis and tumorigenesis via the JAK/STAT pathway in intestine. Cell Mol Gastroenterol Hepatol. 2020;10(4):729-46.

33. Kazemian E, Amouzegar A, Akbari ME, Moradi N, Gharibzadeh S, JamshidiNaeini Y, Khademolmele M, As'habi A, Davoodi SH. Vitamin D receptor gene polymorphisms affecting changes in visceral fat, waist circumference and lipid profile in breast cancer survivors supplemented with vitamin D3. Lipids Health Dis. 2019;18(1):161.

34. Murray A, Madden SF, Synnott NC, Klinger R, O'Connor D, O'Donovan N Gallagher W, Crown J, Duffy MJ. Vitamin D receptor as a target for breast cancer therapy. Endocr Relat Cancer. 2017;24(4):181-95.

35. West DC, Pan D, Tonsing-Carter EY, Hernandez KM, Pierce CF, Styke SC, Bowie KR, Garcia TI, Kocherginsky M, Conzen SD. GR and ER Coactivation alters the expression of differentiation genes and associates with improved ER+ breast Cancer outcome. Mol Cancer Res. 2016;14(8):707-19.

36. Lu D, Jing L, Zhang S. Vitamin D receptor polymorphism and breast Cancer risk: a meta-analysis. Medicine. 2016;95(18):e3535.

37. Zhang K, Song L. Association between vitamin D receptor gene polymorphisms and breast cancer risk: a meta-analysis of 39 studies. PLoS One. 2014;9(4):e96125.

38. Xu Y, He B, Pan Y, Deng Q, Sun H, Li R, Gao T, Song G, Wang S. Systematic review and meta-analysis on vitamin $\mathrm{D}$ receptor polymorphisms and cancer risk. Tumour Biol. 2014;35(5):4153-69.

39. Raimondi S, Johansson H, Maisonneuve P, Gandini S. Review and metaanalysis on vitamin $\mathrm{D}$ receptor polymorphisms and cancer risk. Carcinogenesis. 2009;30(7):1170-80

\section{Publisher's Note}

Springer Nature remains neutral with regard to jurisdictional claims in published maps and institutional affiliations.

Ready to submit your research? Choose BMC and benefit from:

- fast, convenient online submission

- thorough peer review by experienced researchers in your field

- rapid publication on acceptance

- support for research data, including large and complex data types

- gold Open Access which fosters wider collaboration and increased citations

- maximum visibility for your research: over $100 \mathrm{M}$ website views per year

At BMC, research is always in progress.

Learn more biomedcentral.com/submissions 